\title{
Are the discounts in UK open offers and placings due to inelastic demand?
}

\author{
Seth Armitage \\ University of Edinburgh, UK \\ Dionysia Dionysiou \\ University of Stirling, UK \\ Angelica Gonzalez \\ University of Edinburgh, UK
}

7 July 2012

\begin{abstract}
This paper investigates the large and diverse discounts in UK open offers and placings. Large discounts are a substantial cost to shareholders who do not buy new shares. The existing literature mainly examines US firm-commitment offers and private placements, but UK open offers and placings differ from both types of US offer. The paper presents evidence that inelastic demand, illiquidity of the issuer's shares, and financial distress are key determinants of the discount. The effects of inelastic demand and distress are much more apparent in UK than in US SEOs. We argue that institutional features obscure the role of these variables in the US context.
\end{abstract}

Key words: seasoned equity offer; discount; inelastic demand; open offer; placing JEL Classifications: G30, G32

\section{Acknowledgements}

We are grateful for comments from seminar participants at the Universities of Edinburgh and Stirling, Heriot-Watt University, and the British Accounting and Finance Association Conference 2012. 


\section{Introduction}

It is usual for the offer price in seasoned equity offers (SEOs) to be set below the midpoint market price of the issuer's shares immediately before the issue is announced. This discount, or underpricing, provides a reward to investors who buy the new shares, and is a cost to existing shareholders who do not buy the shares, or who buy fewer than the number needed to maintain their percentage holding. The current paper is the first detailed study of the discounts in UK open offers and placings. In our sample $90 \%$ of open offers and placings are at a discount, and the average discount to the pre-announcement market price as a percentage of the offer price is $26 \%$ (median 11\%). This is much larger than the average discount of around $3 \%$ in US firm-commitment offers, but is comparable to the discount in US private placements.

The purpose of the paper is to investigate the large cross-sectional differences across discounts in open offers and large placings, of at least five per cent of the existing equity. There have been several enquiries by government bodies and academic researchers into the direct costs of SEOs, the most recent being by the Office of Fair Trading (OFT, 2011). Yet discounts are on average a bigger cost for nonsubscribers, as the paper documents, and there are many nonsubscribers: it is common for existing shareholders not to buy new shares in open offers and placings, despite the presence of substantial discounts (Armitage, 2010). A large discount is an especial concern to shareholders if they do not have an automatic 'preemption' right to buy new shares, because then they may not be given the opportunity to buy any of the discounted shares. Placings have become the most common method of issue in the $\mathrm{UK}$, and there is no pre-emption right in a placing.

We argue in Section 2 and the Appendix that institutional differences between the USA and UK mean that, a priori, there are only three potential explanations for discounts, and for the cross-sectional variation in discounts, that are relevant to the bulk of UK offers. These explanations are inelastic demand for the shares, information asymmetry, and financial distress of the issuer. Consider, first, elasticity of demand or liquidity of the shares. ${ }^{1}$ An SEO involves an increase in the supply of shares for sale when the issue is being marketed, and the number of new shares is usually many times larger than the average number of existing shares traded per day. The median multiple of new shares over the average number traded per day is 195 times (Table 1). Many of the shares in our sample are very illiquid, and we conjecture that there is a downward-sloping demand curve for such shares.

\footnotetext{
${ }^{1}$ The elasticity of demand for a share and its liquidity are difficult to separate both conceptually and empirically, as discussed in Section 2.2.
} 
Demand for a given share will be less than perfectly elastic if (i) there is a limit to the number of shares a given investor is willing to buy at a given price, and (ii) there is a limit to the number of investors willing to buy any shares at a given price. Regarding (i), several factors could limit demand on the part of a given investor. A large enough holding could imply unwanted active involvement in the company, or impair the diversification of the investor's portfolio, or be costly to sell; it might be costly to raise sufficient cash to buy a large block, and a managed fund might have a limit on how much the fund can hold in any one company. Regarding (ii), there is evidence that investors disagree about the value of a given company, and that they re-appraise their valuations at the time of major corporate events. Chen, Hong and Stein (2002) and Moeller, Schlingemann and Stulz (2005) argue that an increase in unfavourable re-evaluations by shareholders explains, respectively, negative momentum in stocks and large falls in share price on announcement of takeovers. Armitage (2010) finds evidence of limited demand on the part of investors in UK open offers and placings. Institutional investors are the main buyers, and they very rarely accumulate a stake in a given company in excess of $20 \%$. He also finds evidence of heterogeneous valuations of issuers; on average, more than half of the existing shareholders do not buy any new shares, despite the substantial discounts. The idea of Hertzel et al (2002), that firms making placements are overvalued, and that as a result placees are able to negotiate a purchase price well below the market price, envisages disagreement about value between market investors and placees. In addition, there is a variety of other evidence that the demand for shares is materially less than perfectly elastic (Gao and Ritter, 2010, and Huang and Zhang, 2011, include reviews). ${ }^{2}$

It is plausible that there are separate markets for the new and existing shares, which is necessary for inelastic demand to be able to explain the existence of a discount. Through the bookbuilding or placing process, the arranging bank estimates the demand schedule and sets an offer price at which there will be buyers for all the new shares. The prices of trades of existing shares need not be much affected by the fact that many new shares are about to be issued. The marketing of the new shares is a separate process from normal trading, involving direct contact between the company and selected potential buyers, and transmission of private information. These points are especially applicable in UK open offers and placings, because all or most of the marketing is done on a discreet basis before the offer is publicly announced.

\footnotetext{
${ }^{2}$ Ivashina and Sun (2011) provide further evidence and discussion of the effects of inelastic demand on the sale process and pricing of financial assets, in this case syndicated loans. In their view, 'the syndication process matches borrowers with the set of investors with the highest valuations' (p. 505). This is exactly the function of the placing process for equity, if investor demand is seen as inelastic.
} 
The impending issue is price-sensitive information, and investors who agree to become informed about the issue also agree not to trade in the relevant company's shares until after the issue is announced. Only investors contacted by the arranger should know about the issue during the pre-announcement marketing process. Investors ignorant of the offer will continue to trade shares via the normal market process. Hence, there is a separation between the primary market for new shares and the secondary market for existing shares during the preannouncement marketing period, at the end of which the offer price is set. Huang and Zhang (2011) discuss why the primary and secondary markets are partially separate in the case of US firm-commitment offers.

An alternative view to the above is that the increase in the supply of shares will drive down the market price of the existing shares during the period in which the new shares are being marketed. There will be temporary 'price pressure'. Inelastic demand reduces the offer price because it reduces the market price at the time the offer price is set. Loderer, Cooney and Van Drunen (1991) report a negative average abnormal return on the announcement of firm- commitment offers by regulated firms. They argue that as information asymmetry is low for such firms, the price fall is partly explained by inelastic demand. Altinkiliç and Hansen (2005) and Meidan (2005) find weak evidence of temporary price pressure during the bookbuilding period in firm commitments. Gao and Ritter (2010) argue that the purpose of the marketing effort during firm commitments is to increase demand elasticity in order to reduce downward pressure on the share price. ${ }^{3}$ These papers ignore the existence of discounts in firm commitments. The implication is that the main potential impact of inelastic demand is on the share price rather than on the discount. This approach is easier to justify when the mean discount is $3 \%$, as in firm commitments, than when the mean is $26 \%$, as in open offers and placings. In addition, there is no existing evidence for price pressure in open offers and placings. The average abnormal return is positive on announcement of both types of offer, contrary to the predictions of the price-pressure explanation.

An important potentially competing explanation for discounts, beyond inelastic demand and illiquidity, is information asymmetry. ${ }^{4}$ Numerous studies find that discounts are related to variables interpreted as proxies for the transparency of the issuing firm. Despite the intuitive appeal of information asymmetry as an explanation for discounts, there is no accepted theory

\footnotetext{
${ }^{3}$ Several early papers hypothesise that, if the negative average abnormal return on announcement of firmcommitment offers is due to inelastic demand, there should be a negative relation between the abnormal return and the relative offer size. The evidence is mixed; Armitage (1998) includes a brief review.

${ }^{4}$ Information asymmetry could be a reason for inelastic demand: lower transparency could result in fewer investors who would consider buying the shares, and greater heterogeneity of investors' valuations.
} 
that links the two. The well-known Myers-Majluf (1984) theory, which assumes information asymmetry, predicts a fall in the market price on announcement of the issue, but it does not predict the existence of a discount. Hertzel and Smith (1993) argue that discounts in private placements are compensation for the cost to placees of investigating the issuer, a cost which is necessary in order to reduce uncertainty about the value of the issuer. But this explanation has not gained acceptance, partly because the size of many placement discounts would imply implausibly large costs of investigation (Barclay, Holderness and Sheehan, 2007).

A third possible explanation, at least for some discounts, is that the issuer is in financial distress. There are at least two reasons why distress might affect the discount. First, both agency costs and information asymmetry could be more severe for firms in distress. Second, in cases of severe distress, where the alternative to raising equity is likely to be bankruptcy, we might expect suppliers of external equity to be able to extract additional value for themselves, beyond that available in an offer by a non-distressed issuer. External capital is needed to maintain the value of the issuer as a going concern. Some or all of this goingconcern value would be lost if the issuer were to enter bankruptcy proceedings. Knowing this, an external investor should be able to bargain to obtain some of the going-concern value that would be lost in the absence of external funds.

Our research investigates the extent to which variables linked to the above three explanations can explain cross-sectional differences in discounts. In particular, we seek to test whether discounts are explained better by inelastic demand or by information asymmetry. We calculate eight proxies for demand elasticity, namely three measures of offer size in relation to the size of the issuer, four measures of liquidity, and issuer size. We also attempt to isolate the impact of information asymmetry on discounts. Four variables are calculated which ought to proxy for information asymmetry, but which are not measures of inelastic demand or liquidity. Three are measures of earnings quality; they are among the measures calculated by Lee and Masulis (2009), who study the impact of information asymmetry on the direct costs of SEOs.

All the proxies for inelastic demand are statistically significant individually, both in a simple univariate test and in multivariate regressions that include the non-elasticity variables. However, tests show that multicollinearity is a problem in regressions that include combinations of the elasticity variables, with the consequence that some of the elasticity variables do not exhibit consistent levels of significance across different regression specifications. In view of this problem of multicollinearity, we use principal components 
analysis to create a single elasticity variable derived from seven of the individual variables. ${ }^{5}$ This single variable is the first principal component, and it is always highly significant. In contrast, none of the four measures of information asymmetry is significantly related to the discount in a multivariate setting, though there is some univariate evidence of a relation between earnings quality and discount. We find, in addition, financial distress has a major impact on the discount.

The results show very clearly that differences across shares in elasticity of demand or liquidity are able to explain variation in discounts. Financial distress is an additional significant explanatory variable. In contrast, differences in information asymmetry have little explanatory power. A possible explanation for the latter finding is that our proxies for information asymmetry are unreliable due to data limitations. Quantile regressions indicate that the variables have most explanatory power for large discounts, though the elasticity variable is significant in all the quantiles.

The importance of demand elasticity and financial distress is not as evident in existing research, most of which is on US firm-commitment offers or on private placements. This is partly because institutional differences mean that there are more possible explanations for discounts in US than in UK SEOs, as mentioned above. The contrast between firm commitments and placements also matters. Discounts are small in firm-commitment or public offers, and much less varied than in UK SEOs. We offer two suggestions why inelastic demand does not result in large or varied discounts in firm commitments. First, companies choosing firm commitments are much larger than those choosing private placements, and larger size is associated with greater elasticity of demand and liquidity of the shares. ${ }^{6}$ Second, firm-commitment offers are marketed by an underwriting syndicate during the public bookbuilding period, with the purpose of creating demand (Gao and Ritter, 2010; Huang and Zhang, 2011). In UK open offers and placings the pre-announcement marketing is conducted on a private basis, typically be a single bank. It is possible that arranging banks place less reliance on marketing to generate demand, and more on the discount, than is the case in the USA.

Discounts in private placements are much larger. However, they are not viewed as arising from inelastic demand, because there are usually only one or two buyers, and because the restriction on re-sale of the new shares in US placements is on its own a possible reason

\footnotetext{
${ }^{5}$ Principal components analysis has not been used in previous research on discounts in SEOs, but the nature of our investigation and of the results mean that it is a natural step to deploy this technique.

${ }^{6}$ In the sample of Chen, Dai and Schatzberg (2010), the median firm-commitment issuer has a book value of assets that is 14.7 times larger than the median placement issuer (p. 108).
} 
for large discounts. There is no restriction on selling the new shares in UK SEOs, and there are normally at least 20 buyers in open offers and large placings.

Financial distress has not been identified as an important explanatory variable in studies of discounts in US SEOs. That might be because its impact is on the choice of issue method and type of security issued. Many distressed US companies choose a private placement rather than a public offer, or an issue of convertible securities, or a placement combined with warrants (Chen, Dai and Schatzberg, 2010). In the UK, distressed companies tend simply to issue 'straight' equity at a deep discount.

The next section outlines the relevant SEO procedures and reviews previous research on discounts. Section 3 explains the research method and data. Section 4 presents the results on discount and on cost. Section 5 concludes.

\section{Background and previous research}

\subsection{Types of offer}

Since much of the existing evidence is from the USA, a little background is needed on UK SEOs. In an open offer the shares are placed by private negotiation - a discreet bookbuilding process - before the offer is formally announced. Investors who have been contacted by the arranging bank, and who wish to buy shares, provide verbal agreements to buy before the announcement, and the agreements are normally signed on the announcement day. The shares are then offered on a pro rata basis to existing shareholders after the announcement, and the offer is open for at least two weeks. The entitlements to buy new shares cannot be traded, unlike in a rights issue. In a placing, the process is the same except that there is no pro rata offer following the announcement. The offer price in both types of offer is normally set the day before the offer is publicly announced. The new shares are issued the day after the extraordinary general meeting that is normally necessary to authorise the open offer or placing; this meeting is held three to four weeks after the announcement. ${ }^{7}$

In both types of offer, there are typically at least 20 buyers, the bulk of which are investing institutions (Armitage, 2011). Discounts are substantial and there is wide variation across issues. The discount is a cost to shareholders who do not buy new shares, or do not take up all of their entitlement in an open offer. For example, if the share price before the

\footnotetext{
${ }^{7}$ Two other issue methods are employed in the UK. In a rights issue, shareholders can sell their rights, and because of this, the cost of the discount to nonsubscribers depends in part on the cost of selling the rights. In an accelerated bookbuilding, the arranging bank announces the issue and invites institutional investors to bid for the shares. The book is usually closed within one day. This latter method tends to be used by large companies to raise small amounts of equity in relation to their size. Discounts are small (a few per cent). We do not examine either rights issues or accelerated bookbuildings.
} 
announcement of the issue is $£ 1.00$, the offer price is $£ 0.90$, and the share price remains at $£ 1.00$ after the announcement, the reward to buyers of the new shares is $11 \%$ of the offer price. The share price might be expected to fall because of news of the discount. However, the average abnormal return is positive on announcement of open offers and placings (Armitage, 2012, includes a summary of the evidence). If the share price does not fall, it might appear as though nonsubscribers do not lose because of the discount. But if the offer price in the example had been higher than $£ 0.90$, and all else had been the same, the share price would have been higher than $£ 1.00$ after the announcement. ${ }^{8}$

Turning to US SEOs, in a firm-commitment or public offer, the new shares are sold via a bookbuilding process which starts when the offer is announced and ends three or four weeks later, just before the shares are issued. The offer price is set the evening before the issue date. Since the early 1990s the offer price has been set on average $3 \%$ below the market price as at the close of the day before the issue date. Most discounts are clustered within a few percentage points of $3 \%$ (Altinkiliç and Hansen, 2003, Figure 1). In a private placement, the shares are placed by private negotiation with one or a few investors. The new shares initially are not registered with the SEC, and they cannot be sold until they are registered, except via private negotiation. In recent years private investment in public equity (PIPE) placements have become the norm. Registration typically occurs within 60 days of signing the placement agreement, instead of after the one-year delay that applied in earlier placements (six months from February 2008; Maynes and Pandes, 2010). The lead investor in US placements is usually a private-equity, venture-capital or hedge fund, or an individual, or another company. Participation by mainstream institutional investors is limited, in contrast to the case in UK open offers and placings. The average discount to the market price in private placements was around $16 \%$ in the 1990s and $10 \%$ in the 2000s (Huson, Malatesta and Parrino, 2009), but nearly one fifth of US placements are made at a premium (Dai, 2007). So discounts in placements are much larger and more variable than in public offers.

Open offers and placings resemble US firm commitments in that the new shares are bought by more than one or two buyers, following a bookbuilding process (although bookbuilding is discrete in the $\mathrm{UK}$ and is normally completed before the issue is publicly announced). However, the discounts in open offers and placings are much deeper and more variable than in firm commitments, resembling those found in US private placements.

\footnotetext{
${ }^{8}$ No change in the share price implies either that the issue and its offer price of $£ 0.90$ were already expected by the market, or that good news was announced at the same time as the issue, which offset the impact of selling new shares at below the market price. Either way, an offer price higher than $£ 0.90$ implies an increase in the share price on announcement.
} 


\subsection{Determinants of discounts}

Several explanations for discounts in SEOs have been proposed. Here we discuss those which are potentially important for UK open offers and placings. Explanations which do not apply, or which are unlikely to be important, are reviewed in the Appendix.

Inelastic demand. A larger offer in relation to the size of the issuer is associated with a deeper discount, and this is often seen as evidence for inelastic demand in firm-commitment offers (for example, Corwin, 2003). Intintoli and Kahle (2009) find that relative size is a more significant explanatory variable when offer size is measured as a proportion of the free float, which supports the inelastic-demand interpretation. Huang and Zhang (2011) view the number of lead underwriters as a proxy for marketing effort, and they argue that the benefit of marketing is greater elasticity and a smaller discount. They find a negative relation between the discount and the number of co-lead underwriters. They also show that if an investor has a prior relationship with an underwriter, this increases the probability that the relevant investor will participate in the offer. The discount is negatively related to the number of 'relationship investors' of the lead and co-underwriters. Unfortunately, the number of colead managers cannot be used as a proxy in the UK context, because most issues have one arranger only and the maximum in our sample is three. Gao and Ritter (2010) present evidence that the marketing of the offer in firm commitments increases the short-run elasticity of demand for the shares, and that firms with relatively inelastic demand are more likely to choose a firm-commitment offer instead of accelerated bookbuilding, which involves much less marketing. ${ }^{9}$

Inelastic demand has not been considered explicitly as an explanation for discounts in placements. However, some findings are suggestive. The discount is positively related to the relative size of the issue (Hertzel and Smith, 1993; Maynes and Pandes, 2010) and to the number of placees (Wruck and Wu, 2009; Huson et al, 2009). In addition, the argument that placements exist partly to enable the placee(s) to obtain costly private information about the issuer assumes that demand at the prevailing market price from less well-informed investors is insufficiently elastic.

For the UK, Armitage (2007) studies discounts in placings of large blocks of rights to new shares that have been renounced by the shareholders entitled to them. The discounts are

\footnotetext{
${ }^{9}$ Consistent with the hypothesis that the marketing effort is greater when demand is inelastic, Butler, Grullon and Weston (2005) present evidence that the direct cost of firm commitments is negatively related to the liquidity of the issuer's shares.
} 
positively related to bid-ask spread and relative issue size. He interprets this as evidence for inelastic demand.

The elasticity of demand and liquidity of a given share are closely linked conceptually and empirically, and causality plausibly runs in both directions. It is hard to conceive of a liquid share with very inelastic demand, or an illiquid share with very elastic demand. Proxies for elasticity, such as bid-ask spread or the price impact of share trades, are also measures of liquidity. For these reasons we do not try to distinguish between demand elasticity and liquidity as explanations for discounts. Information asymmetry, on the other hand, is a more distinct concept. Information asymmetry could be a reason for a high cost of trading, as in some formal models of the bid-ask spread, and a higher cost implies lower liquidity. However, information asymmetry is not the only possible reason for inelastic demand. For empirical research, measures of information asymmetry can be constructed that are quite distinct from measures of liquidity or elasticity, as Lee and Masulis (2009) emphasise.

Information asymmetry. Several studies, starting with Altinkiliç and Hansen (2003) and Corwin (2003), find that the discount in firm commitments is positively related to proxies for asymmetric information. Most of these studies do not set out in a formal way why information asymmetry might result in a discount. An exception is Hertzel and Smith (1993), who argue that discounts in private placements compensate investors for costs of investigating the issuer, and that the costs increase with the opacity of the issuer. Hertzel and Smith see the opportunity for a placee to investigate the issuer, and become better informed, as a benefit of the placement method. Consistent with this idea is evidence that firms choosing a private placement tend to be much smaller and less profitable than firms choosing a firm-commitment offer (Chen et al, 2010). Similarly, greater opacity is associated with choice of a private placement instead of a rights issue in Sweden (Cronqvist and Nilsson, 2005). These findings suggest that placements are chosen by firms for which access to private information is especially valuable to investors.

An alternative explanation that is based on information asymmetry is that the placees' access to private information enables them to identify firms with overvalued share prices and to bargain down the issue price accordingly. Hertzel et al (2002), Krishnamurthy et al. (2005) and Chaplinsky and Haushalter (2010) find that, while the average long-run abnormal return after placements is negative if the shares are bought at the post-announcement market price, the benefit of discounts means that the long-run abnormal return from buying placement shares is approximately zero. There is also evidence that discounts in firm commitments are deeper in issues preceded by a large run-up of the issuer's share price (Altinkiliç \& Hansen, 
2003; Corwin, 2003). Iqbal, Espenlaub and Strong (2009) report positive average abnormal returns preceding UK open offers. These results suggest that some companies time offers for when they believe they are overvalued, and that buyers of the shares can identify overvaluation.

Financial distress. Few existing studies include distress as an explanatory variable, although it would seem to be a natural candidate. Hertzel and Smith (1993) and Huson et al (2009) include a distress dummy in their studies of placement discounts, but they find it to be insignificant and only significant at the 5\% level, respectively. However, distress is likely to be a reason for choosing a private placement rather than a public offer, and for issuing securities convertible into equity. Chaplinsky and Haushalter (2010) and Chen et al (2010) note that the majority of PIPEs are made by loss-making issuers, either because the firm is at an early stage of product development, or because it is in financial distress. Chen et al argue that PIPEs tend to be chosen as a last resort by companies that would find a firm-commitment offer impossible or more expensive. Chaplinsky and Haushalter argue that a deep discount might exacerbate adverse-selection and agency risks facing investors, in the same way as charging a high price for a loan might exacerbate such risks for a lender. They study a sample that consists of PIPEs at a discount, PIPEs with warrants attached, and issues of convertible preferred shares or debt, which have conversion terms that depend on the issuer's future share price ('resets'). Forty-three per cent of their sample consists of resets or issues with warrants. These instruments are viewed as reducing the contracting risks facing investors, and resets in particular are used in cases of severe distress.

In the light of the existing evidence, a key empirical question for UK open offers and placings is whether differences in discounts are better explained by differences across issuers in information asymmetry, or in elasticity of demand. The extent to which financial distress affects discounts also warrants investigation.

\section{Research method and sample}

\subsection{Dependent variables}

We investigate which variables can explain discounts and costs by means of univariate comparisons and cross-sectional regressions. Our primary measure of the discount is calculated in relation to the pre-announcement share price:

$$
\text { Disc }=\left(P_{\text {ad-1 }}-P_{\text {offer }}\right) / P_{\text {offer }}
$$


where $P_{a d-1}$ is the midpoint share price at the close of the day before the announcement day (AD), and $P_{\text {offer }}$ is the offer price. ${ }^{10} P_{a d-1}$ is taken from the prospectus, when it is stated, and otherwise from Datastream (the price is unadjusted for subsequent capital changes). Sometimes the prospectus records a pre-announcement price for a date earlier than AD-1, on the grounds that this was the last date before production of the prospectus. Since the offer price has to be set before the prospectus is finalised, and since we are interested in the determination of the discount using the last possible share price before the offer price is set, we use the price in the prospectus even if the date precedes AD-1. The Appendix provides further detail on the calculation of discounts, and describes three alternative measures.

\subsection{Explanatory variables}

Proxies for demand elasticity and liquidity of the shares. We use three measures of relative offer size, namely the number of new shares divided by the number of existing shares, $N_{\text {new }} / N_{\text {old }}$ (Relsize1); new shares divided by the number in the free float five days before the announcement, $N_{\text {new }} / N_{\text {freefloat }}$ (Relsize2); and new shares divided by average daily trading volume, $N_{n e w} / \mu \operatorname{Vol}_{t}$ (Relsize3), where $\mu$ is average and Vol $_{t}$ is volume of trading on day $t . \mu \mathrm{Vol}_{t}$ is measured over AD-250 to AD-1. At first glance, relative offer size appears to be a good proxy for elasticity because, conceptually, it is not also a proxy for information asymmetry. But smaller companies tend to make larger offers in relation to their size (Table 2), so in fact relative offer size is correlated with measures of information asymmetry.

We are able to include two of the four proxies for elasticity in Gao and Ritter (2010). First, Inverse elasticity is a measure of how sensitive the share price is to trading volume on a given day $t$, calculated as $\mu\left[\left|R t n_{t}\right| \div\left(\operatorname{Vol}_{t} / N_{\text {old }, t}\right)\right]$, i.e. it is the average of the absolute return on a given day divided by the proportion of shares in issue traded on that day, measured over $\mathrm{AD}-250$ to $\mathrm{AD}-1$. A larger number indicates greater inelasticity. The second measure is Volatility, the standard deviation of the pre-announcement abnormal returns, calculated using the variance of the errors from the market model over AD-250 to AD-1 if the data are available (a minimum of 30 trading days is required). The index model is also used as a robustness test, and it yields similar results. ${ }^{11}$

\footnotetext{
${ }^{10}$ The discount is expressed as a percentage of the offer price because this is how it is defined in most previous studies, and because the direct cost is always expressed as a percentage of the offer price. However, this definition means that a discount greater than $100 \%$ is possible. We go on to cap the discount at $100 \%$.

${ }^{11}$ The third proxy in Gao \& Ritter is the proportion of the shares not owned by institutional investors as at AD1. The proportion of institutional ownership is available from Datastream for 310 of the 449 issues at a discount, though we are unsure about the ultimate source and reliability of these data. Because this variable is missing for many issues in our sample, and because of our doubts about its reliability, we do not include it in our reported
} 
Many of the shares in our sample are highly illiquid, with high proportions of days with no trades. Lesmond (2005) and Bekaert, Harvey and Lundblad (2007) find that, when illiquidity is severe, measures that incorporate daily trading volume, such as Inverse elasticity, are not highly correlated with the bid-ask spread and other measures of liquidity. This suggests that Inverse elasticity may not be a reliable measure in our sample. The preceding authors view the proportion of days with no trading as a reliable measure in illiquid markets. For this reason, we also use \%notrade, the percentage of days with no trading during $\mathrm{AD}-250$ to $\mathrm{AD}-1$, as a direct measure of liquidity and elasticity. ${ }^{12}$

Finally, we include two further variables that are widely used as proxies for liquidity: the quoted bid-ask Spread, calculated as the average of $\left(P_{a s k, t}-P_{b i d, t}\right) /\left[\left(P_{a s k, t}+P_{b i d, t}\right) / 2\right]$ over AD65 to AD-5, and Issuer size, measured by $P_{a d-5} N_{\text {old }}$. In summary, there are eight proxies for elasticity. Three are measures of relative offer size, four of liquidity, and one of issuer size. Volatility, Spread and Issuer size are also commonly used as proxies for information asymmetry.

Proxies for information asymmetry. We try to distinguish between demand elasticity or liquidity, and information asymmetry, by including four variables intended to measure information asymmetry unambiguously. The first is Tangibility, defined as $(P P E+$ cash $) /$ assets, the proportion of assets represented by plant, property, equipment and cash on the balance sheet for the end of the financial year preceding the year of the SEO. A higher value for this variable indicates less information asymmetry. ${ }^{13}$ Although asset tangibility is widely used as a measure of information asymmetry, it is possibly not a good measure in the UK context. Some companies in the sample do not report any intangible assets on their balance sheet, in which case Tangibility is usually given by one minus the proportion of stocks plus debtors in total assets. This will not reflect information asymmetry unless we believe that stocks and debtors are harder to value than plant, property and equipment. The other three variables are used in Lee and Masulis' (2009) study of the direct costs of firmcommitment offers. They are measures of the quality of a firm's accounting information, which are argued to be relatively clean measures of information asymmetry. $M D D$ and

analyses. We find in unreported results that non-institutional ownership is not significantly correlated with any of the other proxies for demand elasticity, and that it is not significant in either univariate or multivariate analyses. The fourth proxy in Gao and Ritter is the stock's average price impact per trade, using TAQ data. We cannot calculate this measure as we do not have data on individual trades.

${ }^{12}$ Eleven shares in the sample have no trades recorded on any of the 250 days. We exclude these from analyses involving \%notrade and Inverse elasticity, as the trading data might be missing for these shares.

${ }^{13}$ The source of the data for Tangibility is Datastream. Where PPE or Cash is missing in Datastream, the relevant numbers are taken from the accounts in the prospectus, if the accounts are provided. 
$A M D D$ are versions of the Dechow and Dichev (2002) measure of earnings quality; $A D A$ is a version of the Kothari, Leone and Wasley (2005) measure of discretionary accruals. The calculation of the three earnings-quality variables is described in the Appendix. These measures are secondary in Lee and Masulis (2009), in that they are used for robustness checks of their main results. Both of the primary measures in Lee and Masulis require eight consecutive years of accounting data per firm, up to the year of the SEO. This requirement is met for only a small minority of the firms in our sample.

Proxies for financial distress. Three mutually exclusive dummy variables are included that indicate the financial status of the company. Distress $=1$ if the prospectus says the issuer is likely to go into liquidation unless the issue proceeds; Loss $=1$ if the issuer has made a pretax loss in the two financial years preceding the issue; Plannedloss $=1$ if the issue has made losses in the past two years, but the losses appear to be expected because the company is at an early stage of development and sales are zero or very low. A positive relation is expected between the discount and each of these dummy variables. The relation should be weakest for Plannedloss.

Control variables. Several control variables are included. The first is a dummy to capture the effect of any market timing by issuers: Highrunup $=1$ if the abnormal return on the share calculated during AD-60 to AD-1 is in the top decile when shares are ranked by preannouncement abnormal return. If some companies time their issues following an exceptional run on their shares, they may offer a deeper discount to counteract potential investor concern about overvaluation. The second is a dummy variable to identify underwritten issues: Underwritten $=1$ if the issue is underwritten in full or in part by the arranging bank. It is possible that the discount will be set deeper in an underwritten issue, in order to reduce the risk to the arranging bank. ${ }^{14}$ We also include dummy variables for year of issue and industry of the issuer (the results are similar without these dummy variables).

\subsection{Sample}

Our initial sample consists of all open offers and placings with a prospectus by UKregistered companies during the ten years 1999-2008. Lists of share issues are available from Perfect Information and from the London Stock Exchange website. Data about the issue are hand-collected from prospectuses, obtained from Perfect Information and Companies House,

\footnotetext{
${ }^{14}$ In a previous version we include a low-price dummy: Lowprice $=1$ if $P_{a d-1}<20 \mathrm{p}$, and zero otherwise. This is intended to control for the effect of rounding in setting the offer price, if any. It is a significant variable in some regression specifications. However, Lowprice is a proxy for information asymmetry, distress, and illiquidity, and because of this muddiness about what Lowprice measures, we exclude it.
} 
and market and accounting data are from Datastream. We require issues to have a prospectus in order to have a reliable source of information about the issue, and to ensure that the issue is worth more than five per cent of the existing equity (placings of five per cent or less do not have a prospectus). We exclude issues (i) by an investment trust or other investment vehicle; (ii) which lack basic information such as a clear announcement date; (iii) where the issuer's shares have been suspended from trading; (iv) where the issuer's share price is three pence or less on the day before the announcement. This last exclusion is to reduce the impact of rounding on percentage discounts when the price is very low. Recorded market prices include tenths and sometimes hundredths of a penny, but the smallest unit in the offer price is half a penny. Many US studies exclude issuers with a share price of two dollars or less. But a similar cut-off, say of one pound, would result in the exclusion of over half of our sample.

Table 1 around here

We are left with 498 issues; 338 open offers and 160 placings. Table 1 presents descriptive statistics. Open offers were more common than placings (worth in excess of 5\% of the equity) during 1999-03, but placings were more common during 2004-08 (see Panel A). The mean discount across the full sample is $22.9 \%$, and the mean for open offers is a little higher than that for placings.

Forty-nine of the issues are at a premium, ie $P_{a d-1} \leq P_{\text {offer }}$. We argue that it is preferable to exclude the issues at a premium, because many of them are different in nature from the issues at a discount. In 24 of the issues at a premium, at least $25 \%$ of the new shares are placed with one or a few buyers who are named in the prospectus. The main buyer is an operating company in seven cases, a private-equity or privately owned investment company in six cases, and a director or directors in 11 cases. Of the remaining 25 issues at a premium, 15 are not underwritten despite being at a premium, which strongly suggests the presence of an undisclosed major buyer willing to pay the premium. When there is a single main buyer who is willing to pay a premium, it is likely that the buyer expects to add value or to obtain private benefits. Hence, we would not expect variables intended to explain discounts and fees to be as relevant for explaining premiums.

Panel B of Table 1 reports descriptive statistics for the sample excluding premiums (all the subsequent analyses exclude premiums). The mean (median) discount in this sample is $25.9 \%(10.5 \%)$, and the mean cost of issue is $8.4 \%(6.7 \%)$. Thus the median cost of the 
discount per new share to a shareholder who does not subscribe for new shares is $57 \%$ greater than the median cost in fees. The typical issuer is quite small, with illiquid shares; the mean market capitalisation is $£ 81 \mathrm{~m}(£ 32 \mathrm{~m})$ and the quoted bid-ask spread is $6.4 \%(5.0 \%){ }^{15}$ The relative offer size, is $92 \%$ (38\%) measured by new shares divided by existing shares, and 537 (195) times measured by new shares divided by daily trading volume. Unfortunately, missing data reduce the sample size materially for Relsize2, \%noninst, and the three measures of earnings quality.

Several of the variables display extreme values and highly skewed distributions. To alleviate this, we use henceforth the natural logarithm of Issuer size, the three measures of relative issue size, Inverse elasticity, and Volatility. We cap the discount at $100 \%$; the mean discount with the cap is $20.8 \%(10.5 \%)$ and the standard deviation is $26.6 \%$. We also winsorize the distribution of the bid-ask spread at its 1st and 99th percentile values.

A final point is that warrants are not a common method of attracting investors in the UK. Only eight issues in our sample include an issue of warrants, of which two are by companies in severe distress. This differs from practice in the USA, where placements by distressed issuers quite often include warrants.

\section{Results}

\subsection{Cross-correlations}

Table 2 around here

Table 2 presents correlations between the discount and the continuous variables used. The highest correlations with Disc are for Spread, Issuer size and the three measures of relative offer size, with coefficients between 0.31 and 0.49 . The highest correlations between the explanatory variables are between the measures of relative offer size, and between Spread and Issuer size (-0.71), i.e. small companies have a large spread. Relative offer size is negatively correlated with issuer size $(-0.56$ for Relsize 1$)$, i.e. smaller companies tend to make larger issues in relation to their size. Several of the other elasticity variables are moderately correlated with each other, including Inverse elasticity with Spread (0.33) and with \%notrade (0.29), and Volatility with Spread (0.30). Issuer size is negatively correlated

\footnotetext{
${ }^{15}$ Half of the spread is a measure of the future cost to buyers of selling their new shares. Most discounts are much larger than the half-spread for the relevant firm, indicating that the half-spread cannot directly explain the bulk of the discount. This assumes that the shares can be sold at the bid price.
} 
to varying degrees with the other elasticity variables, as Gao and Ritter (2010) find. We note that, despite moderate levels of cross-correlation, multicollinearity is present among the measures of elasticity, as explained in Section 4.3.

Regarding the three measures of earnings quality, $M D D 3$ and $A M D D$ are highly correlated (0.69), as expected, and both are modestly correlated with some of the other variables that might proxy for information asymmetry, including Spread, Volatility and Issuer size. However, $A D A$ and Tangibility have low or negligible correlation with $M D D 3, A M D D$, and other possible proxies for information asymmetry, suggesting that they are not reliable measures of information asymmetry in our sample. Tangibility and $A D A$ are the variables that have the least connection with Disc and with the other variables.

\subsection{Regression results}

Table 3 around here

Table 3 shows univariate OLS regression results for all the variables except the year and industry dummies. The dependent variable is Disc. We expect a positive relationship between Disc and all the variables except Issuer size. All eight of the elasticity variables have coefficients with the sign expected if demand is inelastic, and the coefficients are significant with a $p$-value of 0.010 or below. The four proxies for information asymmetry have the expected sign but are much less significant; the most significant is $A D A(p=0.032)$. Distress, Loss and Plannedloss all have the expected sign and are significant, with a $p$-value of 0.010 or below. The same applies to Highrunup. Underwritten has the opposite sign (negative) to the sign expected, and its $p$-value is 0.001 . The significance of Underwritten could be due to the fact that non-underwritten issues are done by smaller companies; the mean market capitalisation for non-underwritten issues is $£ 29.9 \mathrm{~m}$, compared with $£ 112.9 \mathrm{~m}$ for underwritten issues.

Table 4 around here

Table 4 presents multivariate OLS regression results for a selection of models. Coefficients for seven of the elasticity variables are shown in turn, with the non-elasticity variables included. Each of the elasticity variables has the predicted sign and is significant, with a $p$-value of 0.031 or below. The eighth, Relsize 2 , is also significant ( $p=0.000$ ), but we 
do not report regressions that include this variable because the sample size is only $292 .{ }^{16}$ Inverse elasticity has a $p$-value of 0.026 . Its relatively low explanatory power is surprising, since Gao \& Ritter (2010) consider this to be the most effective of their four measures. We suspect that the low trading volumes observed in some of the shares in our sample reduce the effectiveness of this variable in measuring elasticity, as mentioned in Section 3.2.

Of the variables to measure information asymmetry, we only report results for regressions which include Tangibility at this stage, since the samples are smaller for the earnings-quality variables. Tangibility is not significantly related to the discount. This does not support the information-asymmetry explanation for discounts. In unreported regressions, the earnings-quality variables are not significant either.

Distress is consistently highly significant, and Loss is also significant with $p$ below 0.010. Plannedloss has varying levels of significance. Highrunup and Underwritten are not significant in any specification.

We have a number of proxies for elasticity and it is not clear which proxy, or which combination of proxies, gives the best measure. We experiment with various combinations of proxies, and in unreported results we find that the significance of a given proxy is not always consistent across different regression specifications. For example, Spread is not usually significant in models that include Volatility. However, the $F$-test confirms that, whatever other variables are included in a given regression, the elasticity variables are always jointly significant at the $1 \%$ level.

The pairwise correlations reported in Table 2 are mostly not high enough to suggest that multicollinearity will be a serious problem, with one or two exceptions (for example, Spread and Issuer size are highly negatively correlated). Similarly, the variance inflation factor (VIF) test is generally below ten for the explanatory variables in regressions with combinations of proxies for elasticity, indicating that multicollinearity should not be a serious concern. But Greene (1997, p. 421) suggests that multicollinearity will be a concern whenever the overall $R$-squared for a regression is less than one or more of the partial $R$-squareds, ie the $R$-squared for a regression of one of the explanatory variables on the remaining explanatory variables. We find that the partial $R$-squareds for all the elasticity proxies except Inverse elasticity exceed the overall $R$-squareds for any of the regressions in reported in Table 4.

\footnotetext{
${ }^{16}$ For the sample of 292 issues for which we can calculate Relsize 2 , there is little difference in the significance of offer size in relation to existing shares (Relsize1) and free float (Relsize2). So we do not echo the finding of Intintoli and Kahle (2009) for US firm commitments that size in relation to free float has greater explanatory power.
} 
In view of this finding, we argue that principal components analysis is likely to produce a better measure of demand elasticity than any of the individual proxies or combination of these proxies. This technique has been proposed for coping with independent variables that display multicollinearity, as we find in our case, and capture common information. ${ }^{17}$ Given the high collinearity between the elasticity proxies suggested by the partial $R$-squared results, it is likely that a small number of principal components will account for the variation in the Disc. Table 5 presents OLS results with the first principal component, Elasticity, as an explanatory variable. All the loadings for the proxies are positive, which means that the first principal component is a simple weighted average of the seven proxies from Table 4 (Issuer size has the opposite sign to that of the other variables, and so its inverse is used in calculating the principal components). Elasticity is highly significant across all specifications ( $p<0.000$ ), and the $R$-squareds of the regressions are substantially higher than in Table 4 . The regressions in Table 5 include all of the proxies for information asymmetry, but none achieve significance $(p \leq 0.100) .{ }^{18}$ Models 2 and 6 include proxies for information asymmetry without the control variables, to check if asymmetric information is insignificant due to collinearity with some of the control variables. The results suggest that collinearity with control variables does not account for the lack of significance. Distress remains highly significant, with $p$-values below 0.02 , and Loss has $p$-values below 0.06 . If our proxies for information asymmetry are reliable, these results provide clear evidence that inelastic demand, rather than information asymmetry, drives discounts in UK SEOs. Financial distress is an important additional factor. However, as mentioned already, it is possible that Tangibility is a poor measure of information asymmetry. In addition, data limitations mean that we cannot calculate the earnings-quality variables with as many years of data as we would wish. So a possible explanation for the lack of significance of the proxies for information asymmetry is that they do not measure information asymmetry accurately.

\footnotetext{
${ }^{17}$ See, for example, Greene (1997), pp. 424-7. Linck, Netter and Yang (2008) use the principal factor of three variables to proxy for complexity within a board of directors and the principal factor of three variables to proxy for the costs of monitoring and advising. Armstrong, Core and Guay (2012) use a similar methodology to develop an information cost factor that is a function of various firm characteristics, such as firm size, age, growth, investment, and risk. The method is also widely used in the asset pricing literature; 'macro factors' are derived from a principal components methodology.

${ }^{18} \mathrm{We}$ also run the regressions having winsorized the three measures of earnings quality at the 1st and 99th percentile. The results are unaffected.
} 
Table 6 around here

The discounts in our sample differ greatly in size, and the sensitivity of discounts to our explanatory variables might with the size of discounts. In view of this, we use quantile regression to investigate the explanatory power of the variables for different ranges in the distribution of Disc. Table 6 reports coefficients that result from minimising a weighted sum of the absolute values of the errors. For example, the regression quantile for the tenth percentile, q10, results from applying a weight of 0.10 for positive errors and 0.90 for negative errors. So all the data are used, but with different weights. Since negative errors are associated with smaller discounts, q10 primarily estimates the relations between Disc and the explanatory variables for small values of Disc. Quantile regression differs from partitioning the sample by size of the dependent variable, and running OLS regressions for each of the subsamples resulting from the partition. OLS regression for a given subsample ignores data that fall outside the subsample, and partition can lead to sample-selection bias. ${ }^{19}$

The results in Table 6 show that Elasticity is significant at the $1 \%$ level for all the quantiles, vis q10, q25, q50, q75 and q90. However, the effect of elasticity is much larger for the higher quantiles of the distribution; the coefficients on Elasticity are 0.073 for q90 and 0.011 for q10, and 0.050 for q75 and 0.019 for q25 (see the last two columns for tests of the differences between the coefficients). In other words, differences in elasticity of demand explain more of the differences in large discounts than in small discounts. Distress and Loss are only significant for q75 and q90, as would be expected, since these quantiles place most weight on large discounts, ${ }^{20}$ and most distressed issuers have a deep discount. The other variables are never significant. The pseudo $R$-squared of the quantile regressions increases monotonically in moving from q10 to q90, from 0.06 to 0.41 . The results of the quantile regressions show that differences in elasticity across shares, and whether the issuer is in financial distress, are capable of explaining much of the substantial variation observed in the deeper discounts. $^{21}$

\subsection{Robustness checks}

\footnotetext{
${ }^{19}$ For another example of the application of quantile regression, and further discussion, see Hallock, Madalozzo and Reck (2010).

${ }^{20}$ More accurately, the weight of $x$ in the regression quantile for the $x$ th percentile applies to discounts lying above the standard OLS regression line.

${ }^{21}$ We also partition the sample around the median value of Disc, and run OLS regressions for each subsample. The $R$-squared for larger discounts is much larger than for the smaller discounts.
} 
To check whether the results are robust to different measures of discount, we replicate the regression and principal component analyses with each of three alternative measures, detailed in the Appendix, as the dependent variable. The results (not reported) are qualitatively similar. Our variables have similar explanatory power for the average discount calculated over 30 days before the announcement as they do for Disc. The explanatory power is less for the other two measures. The results are also robust to different specifications of the explanatory variables. For example, using unadjusted variables instead of log transformations does affect the main findings.

We note in Section 3.2 that Volatility, Spread and Issuer size are commonly used as proxies for information asymmetry, as well as demand elasticity. To check that the lack of significance of the four unambiguous proxies for information asymmetry is not due to the presence of Volatility, Spread and Issuer size, we run the regressions and principal components analysis without these three variables. The four unambiguous proxies for information asymmetry do not become more significant.

A few of the shares are only traded a handful of times during the 250 days preceding the issue. The presence of such shares might compromise the impact of Volatility on the discount, as they might have low volatility due to absence of trading, but in fact have a very uncertain share price. In addition, the discount might not be reliably measured, if the market price is 'stale'. For this reason we re-run the regressions in Tables 4 and 5 with a sample that excludes the $10 \%$ of issuers with the least actively traded shares. The results are unaffected.

Finally, in 30 of the sample, other securities were issued at the same time as the equity. The results are similar when these issues are excluded. We also try excluding the issues which were made in order to finance a takeover, as the offer price could be affected by the takeover, especially if shares are issued to the target company's shareholders. The results are similar for the sample excluding takeovers.

\section{Conclusion}

The discounts in open offers and placings are large and they vary considerably across different offers. This is the first study to focus on explaining the variation in UK discounts. While most existing evidence focuses on US SEOs, several of the explanations provided are not relevant for the UK, or are unlikely to matter as much. We test the view that the primary explanation for discounts in UK SEOs lies with limited demand on the part of investors and limited liquidity of the shares. 
Our empirical study includes eight proxies for elasticity of demand and liquidity, together with a range of other variables including proxies for asymmetric information and financial distress. Since there is a problem of multicollinearity between the elasticity variables, we use principal components analysis to measure elasticity by means of a single variable, the first principal component. We attempt to distinguish between elasticity and information asymmetry by including four measures designed to measure information asymmetry unambiguously. Three of these four are proxies for earnings quality, following Lee and Masulis (2009).

The results support the hypothesis that inelastic demand and illiquidity are a primary cause of the large and variable discounts observed in the UK. The results also show that severe distress independently adds to the depth of the discount. In contrast, the four proxies for information asymmetry have no explanatory power in our multivariate regressions. But it is possible that the proxies for asymmetric information lack significance because they are unreliable. Quantile regressions reveal that issues with large discounts are more sensitive to elasticity and distress than those with small discounts.

The results add to the evidence that it is difficult and expensive for small-cap companies to raise equity, even if their shares are listed on a stock market. The results suggest that inelastic demand has an important role in explaining the large and diverse SEO discounts in the UK, which are a cost to nonsubscribing shareholders. We recognise, though, that it is difficult to distinguish empirically between information asymmetry and inelastic demand, and, indeed, information asymmetry could be a cause of inelastic demand. The underlying causes of inelastic demand, and its impact on the issuance of securities and on the secondary trading of large blocks, warrant further study. 


\section{Appendix}

\section{A1. Other explanations for discounts that are of little or no relevance in the UK}

Appendix A1 summarises explanations for discounts in US SEOs that are of little or no relevance to UK SEOs. The first is that the new shares in a private placement cannot be sold until registration has been declared effective by the SEC, except through a privately negotiated trade. Bajaj et al. (2001) and Robak (2007) present evidence that this restriction on re-sale accounts for much or all of the discount in US placements, and Maynes and Pandes (2010) find that discounts in Canadian placements became less deep after 2001, when the mandatory restricted period for re-sale was reduced in length. In the UK there is no restriction on when the new shares can be sold, so this key explanation for discounts in placements does not apply in our sample.

Second, several explanations for discounts depend on the fact that in the majority of US placements there is one buyer, or one clearly identifiable lead buyer. (i) Discounts in placements led by a hedge fund are much deeper than in placements led by a venture-capital (VC) fund. In fact, 34\% of VC-led private placements are at a premium. It seems that hedge funds are more willing to make risky, speculative investments, but require a higher expected return via a deeper discount and via other features that enhance expected returns, such as warrants. (Brophy, Ouimet and Sialm, 2006; Dai, 2007; Dai, Jo and Schatzberg, 2010). (ii) A discount could exist to compensate an 'active' investor for their cost of monitoring the issuer after the placement (Wruck, 1989; Wruck and Wu, 2009), although Barclay et al (2007) argue that the placee is passive in most cases. Discounts are less deep, or the placement is at a premium, when the placee is a strategic-alliance partner or another affiliated investor (Wu, 2004; Krishnamurthy et al, 2005). (iii) Incumbent managers could use discounts to reward themselves or a passive placee who will support them $(\mathrm{Wu}, 2004$; Barclay et al, 2007).

There is no lead buyer in bulk of UK open offers and placings. A lead investor is rarely named in the prospectus. Armitage (2010) studies the placees in UK open offers and placings, and finds that the largest placee usually buys substantially less than half the issue. The mean of the number of buyers identified per offer is 29 .

Third, several studies find that, controlling for other factors affecting the discount, superior underwriter reputation is associated with a smaller discount in firm commitments. However, there is no generally recognised ranking of UK arranging banks by reputation. We record the name(s) of the arranger(s) for each SEO in our sample, and we find in untabulated results that there are around 25 banks which are active in the SEO business, each of which 
arranges one or two of the issues per year in our sample. Hence, the business is not concentrated in the UK and there are no obvious market leaders by number of issues. This view is corroborated by the UK Office of Fair Trading (OFT, 2011).

Fourth, Mola and Loughran (2004) argue that the lead bank in firm-commitment offers leaves money on the table for investors by setting the offer price at an integer (of one dollar), below the pre-issue market price. Similarly, deeper discounts for NASDAQ firms could be explained by the practice of setting the offer price at the bid price in the NASDAQ market. Discounts in the UK are mostly too large for pricing at an integer (of one penny) potentially to explain more than a small proportion of the discount.

Finally, Kim and Shin (2004) argue that the discounts in firm commitments are partly driven by the introduction of SEC Rule 10b-21 in 1988, which banned short selling before the issue day, and arguably made the pre-issue market price less informative about value. There is no ban on short selling in the UK. But the offer price is set before the issue is public knowledge, and investors who agree to become informed about the offer before it is announced undertake not to trade in the shares until after the announcement. So possibly the arranging bank views the share price as not fully informative at the time the offer price is set.

\section{A2. Further detail on calculation of discounts}

In cases where the new shares are not entitled to the next dividend, the discount is calculated as

$$
\text { Disc }=\left(P_{a d-1}-\text { Div }-P_{\text {offer }}\right) / P_{\text {offer }},
$$

where Div is the dividend per share to which the new shares are not entitled. The three other measures of the discount described below are also adjusted for non-entitlement to the next dividend.

A few of the issues to fund an acquisition are accompanied by an issue of "consideration shares', that is, shares issued to the shareholders of a company being acquired as full- or partconsideration for the equity. We ignore consideration shares in calculating the discount and offer size, except for consideration shares that are placed on behalf of the recipients, in which case they form part of a normal placing. Implicitly, consideration shares are treated as being issued at the same price as the post-announcement share price.

Some issues are accompanied by a share consolidation, in which case one new share replaces a multiple of existing shares, in order to increase the market price per share (but with no effect on market value). If the consolidation is to take place before the new shares are issued, about four weeks after the announcement, the offer price and number of the new 
shares are expressed in the prospectus on the assumption that the consolidation has already taken place. In this case the price and number of the existing shares must also be amended, so that they too are expressed on a consolidated basis when calculating the discount and relative offer size.

\section{A3. Alternative measures of discount}

In an open offer the existing shares lose their entitlement to new shares on the ex-rights day, which is either the announcement day or the day after. If $P_{a d-1}>P_{o f f e r}$, the entitlement has value as at $A D-1$. The share price will be expected to fall by the value of the entitlement, to the theoretical ex-rights price (TERP) as at AD-1. Allowing for this predictable and mechanical effect, and assuming no change in the value of the issuer as a result of the announcement, the value of the discount is calculated in relation to the TERP:

$$
\text { Disc }_{\text {terp }}=\left(T E R P_{\text {ad-1 }}-P_{\text {offer }}\right) / P_{\text {offer }}
$$

and TERP $P_{a d-1}=\left(P_{a d-1} N_{\text {old }}+P_{\text {offer }} N_{\text {newprorata }}\right) / N$, where $N_{\text {old }}$ is the number of existing shares as at AD-1, $N_{\text {newprorata }}$ is the number of new shares offered pro rata to existing shareholders, and $N=N_{\text {old }}+N_{\text {newprorata }}$ The concept of the TERP only applies to shares offered pro rata, to which the existing shares have an entitlement that ceases on the ex-rights day. If shares are sold at a discount in a placing, with no pro rata entitlement, it is not clear that a fall in the share price would be expected on the announcement day as a result of the discount on the placing shares (see Armitage, 2012, for a full discussion). ${ }^{22}$ Therefore Disc terp only applies to the shares in open offers.

Second, one can argue that companies can anticipate any share-price reaction to the announcement of an issue (ie the 'information effect'). In this case the discount should be measured in relation to the post-announcement share price, and several US studies measure discounts in this way. So we calculate the discount using the observed market price on $\mathrm{AD}+1$ :

$$
\text { Disc } a d+1=\left(P_{a d+1}-P_{o f f e r}\right) / P_{o f f e r}
$$

Third, the offer price might be set in relation to an average of the share price preceding the announcement day; there are occasional statements in prospectuses that the offer price has been set on this basis. The offer price is thereby less affected by any large price movements just before the announcement. We calculate the discount using the average market price over the thirty days before the announcement:

\footnotetext{
${ }^{22}$ Altinkiliç and Hansen (2003) estimate the expected level of discount in firm-commitment offers, from which they derive a value for the discount surprise, which, they argue, should affect the share price on the issue day.
} 


$$
\operatorname{Disc}_{a d-30, a d-1}=\left[\mu\left(P_{a d-30, a d-1}\right)-P_{o f f e r}\right) / P_{o f f e r}
$$

\section{A4. Calculation of three variables measuring accruals quality}

(i) Modified Dechow-Dichev measure (MDD3 in Lee and Masulis, 2009). The following regression is run using the sample of all listed firms in the same industry group as SEO firm $j$, for years $t-2$ to $t$, where $t$ is the financial year in which the SEO took place. Industry groups are defined using the Industry Classification Benchmark classification, level two (11 industry groups), to ensure a good number of companies in each industry.

$$
C A_{j, t}=\alpha+\beta_{1} C F O_{j, t-1}+\beta_{2} C F O_{j, t}+\beta_{3} C F O_{j, t+1}+\beta_{4} \Delta \text { Sales }_{j, t}+\beta_{5} P P E_{j, t}+e_{j, t}
$$

where $C A_{j, t}=$ current accruals for company $j$ in financial year $t$ (change in current assets minus change in current liabilities minus change in cash holdings plus change in debt due within one year), $C F O_{j, t}=$ cash flow from operations (net income before extraordinary items minus current accruals minus depreciation and amortization), $\Delta$ Sales $_{j, t}=$ the change in sales from year $t-1$ to year $t, P P E_{j, t}=$ gross property, plant and equipment, and $e_{j, t}$ is the error term. These variables are scaled by the average of total assets for firm $j$ for year $t-1$ and year $t$. $M D D 3$ for $j$ is given by the standard deviation of the three error terms. The source of the accounting information is Datastream.

(ii) Absolute $M D D(A M D D)$ is simply the absolute value of $e_{j, t}$. This requires two years' less data than does $M D D 3$. The two $M D D$ variables are designed to measure deviation in the value of current accruals from the value that would normally be expected, whether or not the cause of the deviation is deliberate manipulation of accruals and earnings by management.

(iii) Absolute Discretionary Accruals (ADA) Each SEO firm is matched, by return on assets for the financial year $t$ in which the SEO took place, with another firm in the same industry group. For all the firms in firm $j$ 's industry, the following regression is run for year $t$ :

$$
T A_{j, t}=\alpha+\beta_{1}\left(1 / \text { Assets }_{j, t-1}\right)+\beta_{2} \Delta \text { Sales }_{j, t}+\beta_{3} P P E_{j, t}+e_{j, t}
$$

where $T A_{j, t}$ is total accruals (current accruals plus depreciation and amortization), and Assets $_{j, t}$ is total assets. The $A D A$ measure is the absolute value of the difference between $e_{j, t}$ and the error term for year $t$ for $j$ 's matched firm. We also calculate $M D D$ and $A D A$ for the year prior to the SEO, $t=-1$, but the results using the re-calculated $M D D$ and $A D A$ do not change. 
Table 1

Descriptive statistics

In Table 1 all values are calculated from the raw data, with no adjustments. The numbers in the sample for each variable differ because of missing data, because 11 companies with zero trades in the shares are excluded from the \%otrade sample, and because 16 insurance companies and banks are excluded from the Tangibility sample. In defining the explanatory variables, $P_{a d-1}$ is the share price of the issuing company as at the close of the day before the announcement day; $P_{o f f e r}$ is the offer price; $N_{n e w}$ is the number of shares in the issue; $N_{\text {freefloat }}$ is the number of the issuer's shares in the free float five days before the announcement; $\mu V o l_{t}$ is the average daily trading volume in the issuer's shares over the 250 trading days preceding the announcement (AD-250 to AD- 1$) ; \mu\left[\left|\operatorname{Rtn}_{t}\right| \div\left(\right.\right.$ Vol $\left.\left._{t} / N_{\text {old }, t}\right)\right]$ is the average over AD-250 to AD- 1 of the absolute return on a given day divided by the proportion of shares in issue traded on that day; $N_{\text {old }}$ is the number of shares in issue as at the announcement day; Stdev(AR) is the standard deviation of the abnormal returns calculated using the index model for AD-250 to AD-1; $\mu\left\{\left(P_{a s k, t}-P_{\text {bid }, t}\right) /\left[\left(P_{a s k, t}+P_{\text {bid, }, t}\right) / 2\right]\right\}$ is average of the quoted bidask spread for each day over $\mathrm{AD}-65$ to $\mathrm{AD}-5$; \%notrade is the proportion of days with no trading during $\mathrm{AD}-250$ to $\mathrm{AD}-1$; (PPE+cash)/assets is the proportion of asset value represented by plant, property, equipment and cash as at $\mathrm{AD}-1 ; E Q 1: M D D 3$ and $E Q 2: A M D D$ are modified Dechow-Dichev measures of earnings quality, and $E Q 3$ : $A D A$ is a measure of absolute discretionary accruals. The three measures of earnings quality are explained in the Appendix; higher values indicate lower informativeness of earnings. $N$ is the number of observations. Sources: prospectuses for information about the issue, including $P_{a d-l}$ if provided, and Datastream for all other data.

\begin{tabular}{|c|c|c|c|c|c|}
\hline Panel A: all issues & & Open offers & Placings & Full sample & \\
\hline Number: 1999-03 & & 231 & 23 & 254 & \\
\hline 2004-08 & & 107 & 137 & 244 & \\
\hline 1999-08 (full sample) & & 338 & 160 & 498 & \\
\hline Number of issues at a discount: $P_{a d-1}>P_{o f f e r}$ & & 331 & 138 & 449 & \\
\hline Number of issues at a premium: $P_{a d-1} \leq P_{o f f e r}$ & & 27 & 22 & 49 & \\
\hline Mean discount & & $24.3 \%$ & $20.0 \%$ & $22.9 \%$ & \\
\hline Panel B: issues at a discount & Min & Max & Mean & Median & $\mathrm{N}$ \\
\hline Disc: $\left(P_{a d-1}-P_{o f f e r}\right) / P_{o f f e r}$ & $0.4 \%$ & $427.0 \%$ & $25.9 \%$ & $10.5 \%$ & 449 \\
\hline Proceeds: $P_{\text {offer }} N_{\text {new }}$ & $£ 0.6 \mathrm{~m}$ & $£ 570.2 \mathrm{~m}$ & $£ 23.2 \mathrm{~m}$ & $£ 10.5 \mathrm{~m}$ & 449 \\
\hline Offer price: $P_{o f f e r}$ & $1.0 \mathrm{p}$ & $340.0 \mathrm{p}$ & $132.6 \mathrm{p}$ & $57.0 \mathrm{p}$ & 449 \\
\hline \multicolumn{6}{|l|}{ Measures of elasticity } \\
\hline Relsize 1: $N_{\text {new }} / N_{\text {old }}$ & $0.03 \times$ & $118.8 \times$ & $0.92 \times$ & $0.38 \times$ & 449 \\
\hline Relsize 2: $N_{\text {new }} / N_{\text {freefloat }}$ & $0.03 \times$ & $320.9 \times$ & $2.50 \times$ & $0.72 \times$ & 294 \\
\hline Relsize3: $N_{\text {new }} / \mu \mathrm{Vol}_{t}$ & $0.52 \times$ & $39,688.6 \times$ & $536.5 \times$ & $194.5 \times$ & 438 \\
\hline Inverse elasticity: $\mu\left[\mid\right.$ Rtn $_{t} \mid \div\left(\right.$ Vol $\left.\left._{t} / N_{\text {old }, t}\right)\right]$ & $0 \times$ & $684 \times$ & $36 \times$ & $19 \times$ & 438 \\
\hline Volatility: $\operatorname{Stdev}\left(A R_{t}\right) \times 100$ & $0.0 \%$ & $162.3 \%$ & $14.7 \%$ & $7.5 \%$ & 447 \\
\hline Spread: $\mu\left\{\left(P_{a s k, t}-P_{b i d, t}\right) /\left[\left(P_{a s k, t}+P_{b i d, t}\right) / 2\right]\right\}$ & $0.5 \%$ & $50.1 \%$ & $6.4 \%$ & $5.0 \%$ & 449 \\
\hline Proportion of no-trading days: \%notrade & $2.0 \%$ & $99.2 \%$ & $23.1 \%$ & $9.8 \%$ & 438 \\
\hline Issuer size: $P_{\text {ad }-5} N_{\text {old }}$ & $£ 1.1 \mathrm{~m}$ & $£ 1,618.0 \mathrm{~m}$ & $£ 81.4 \mathrm{~m}$ & $£ 32.1 \mathrm{~m}$ & 449 \\
\hline
\end{tabular}


Panel B cont.: issues at a discount

Measures of information asymmetry

Tangibility: (PPE+cash)/assets

EQ1: $M D D 3$

EQ2: $A M D D$

EQ3: $A D A$
Min

$0.3 \%$

$0.00 \%$

$0.00 \%$

$0.00 \%$
$\operatorname{Max}$

$99.9 \%$

$1.99 \%$

$3.15 \%$

$14.30 \%$
Mean

$42.3 \%$

$0.12 \%$

$0.10 \%$

$0.22 \%$
Median

$\mathrm{N}$

$34.5 \%$

$0.06 \%$

$0.05 \%$

$0.10 \%$ 
Table 2

\section{Correlation coefficients}

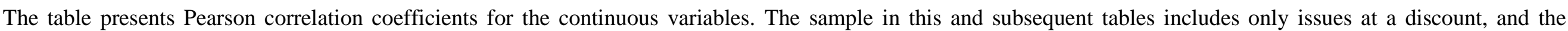

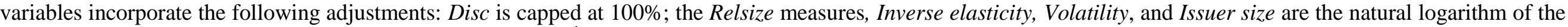
corresponding variables; Spread is winsorized at the $1^{\text {st }}$ and $99^{\text {th }}$ percentiles. The variables are defined in Table 1.

\begin{tabular}{|c|c|c|c|c|c|c|c|c|c|c|c|c|c|}
\hline & Disc & Relsizel & Relsize2 & Relsize3 & $\begin{array}{c}\text { Inverse } \\
\text { elast'y }\end{array}$ & $\begin{array}{c}\text { Volati- } \\
\text { lity }\end{array}$ & Spread & $\begin{array}{c}\% \\
\text { notrade }\end{array}$ & $\begin{array}{c}\text { Issuer } \\
\text { size }\end{array}$ & $\begin{array}{c}\text { Tangib- } \\
\text { ility }\end{array}$ & $\begin{array}{c}E Q 1: \\
M D D 3\end{array}$ & $\begin{array}{c}E Q 2: \\
A M D D\end{array}$ & $\begin{array}{l}E Q 3: \\
A D A\end{array}$ \\
\hline Disc & 1 & & & & & & & & & & & & \\
\hline Relsizel & 0.41 & 1 & & & & & & & & & & & \\
\hline Relsize2 & 0.49 & 0.92 & 1 & & & & & & & & & & \\
\hline Relsize3 & 0.31 & 0.65 & 0.65 & 1 & & & & & & & & & \\
\hline Inverse elasticity & 0.16 & 0.12 & 0.13 & 0.39 & 1 & & & & & & & & \\
\hline Volatility & 0.38 & 0.25 & 0.30 & -0.13 & -0.00 & 1 & & & & & & & \\
\hline Spread & 0.43 & 0.41 & 0.38 & 0.38 & 0.33 & 0.30 & 1 & & & & & & \\
\hline \%notrade & 0.14 & 0.07 & 0.14 & 0.40 & 0.29 & -0.21 & 0.31 & 1 & & & & & \\
\hline Issuer size & -0.38 & -0.56 & -0.48 & -0.42 & -0.19 & -0.22 & -0.71 & -0.28 & 1 & & & & \\
\hline Tangibility & 0.00 & -0.04 & -0.08 & 0.05 & -0.03 & -0.07 & -0.06 & 0.04 & 0.07 & 1 & & & \\
\hline EQ1: MDD3 & 0.14 & 0.07 & 0.09 & 0.06 & 0.11 & 0.19 & 0.26 & -0.01 & -0.19 & -0.07 & 1 & & \\
\hline$E Q 2: A M D D$ & 0.10 & 0.05 & 0.07 & 0.03 & 0.06 & 0.06 & 0.12 & 0.00 & -0.17 & -0.08 & 0.69 & 1 & \\
\hline$E Q 3: A D A$ & -0.00 & 0.02 & 0.00 & 0.02 & 0.01 & 0.02 & -0.00 & -0.00 & -0.05 & -0.09 & 0.03 & 0.18 & 1 \\
\hline
\end{tabular}


Table 3

\section{Univariate results}

The table shows the results of univariate OLS regressions. The continuous variables are defined in Table 1. Distress $=1$ when the prospectus states that the firm is likely to go into liquidation unless the issue proceeds; Loss $=1$ when the firm has losses for the two financial years preceding the announcement, and the losses do not appear to have been anticipated; Plannedloss $=1$ when the firm has losses for the two financial years preceding the announcement, and the losses appear to have been anticipated; Highrunup $=1$ if the abnormal return on the share calculated during AD-60 to AD- 1 is in the top decile when shares are ranked by pre-announcement abnormal return; Underwritten $=1$ when the offer is (at least partly) underwritten.

\begin{tabular}{|c|c|c|c|c|}
\hline & Coefficient & $p$-value & $R^{2}$ & $N$ \\
\hline Relsizel & 0.114 & 0.000 & 0.171 & 449 \\
\hline Relsize2 & 0.117 & 0.000 & 0.242 & 294 \\
\hline Relsize3 & 0.061 & 0.000 & 0.094 & 438 \\
\hline Inverse elasticity & 0.042 & 0.003 & 0.026 & 437 \\
\hline Volatility & 0.086 & 0.000 & 0.144 & 447 \\
\hline Spread & 2.190 & 0.000 & 0.185 & 449 \\
\hline \%notrade & 0.132 & 0.010 & 0.019 & 449 \\
\hline Issuer size & -0.072 & 0.000 & 0.140 & 449 \\
\hline Tangibility & 0.019 & 0.643 & 0.001 & 435 \\
\hline$M D D 3$ & 0.286 & 0.032 & 0.031 & 274 \\
\hline$A M D D$ & 0.256 & 0.061 & 0.019 & 349 \\
\hline$A D A$ & 0.040 & 0.290 & 0.002 & 416 \\
\hline Distress & 0.307 & 0.000 & 0.133 & 449 \\
\hline Loss & 0.087 & 0.010 & 0.018 & 449 \\
\hline Plannedloss & 0.139 & 0.000 & 0.060 & 449 \\
\hline Highrunup & 0.065 & 0.180 & 0.006 & 449 \\
\hline Underwritten & -0.089 & 0.001 & 0.027 & 443 \\
\hline
\end{tabular}




\section{Table 4}

OLS regressions for discounts

The dependent variable is Disc. The continuous variables are defined in Table 1 and the dummy variables, which are from Distress down, are defined in Table 3. The adjustments described in Table 2 are applied. The table reports regression coefficients with heteroscedasticity-robust $p$-values in brackets.

\begin{tabular}{|c|c|c|c|c|c|c|c|}
\hline & Model 1 & Model 2 & Model 3 & Model 4 & Model 5 & Model 6 & Model 7 \\
\hline Relsize1 & $\begin{array}{c}0.085 \\
{[0.000]}\end{array}$ & & & & & & \\
\hline Relsize3 & & $\begin{array}{c}0.049 \\
{[0.000]}\end{array}$ & & & & & \\
\hline Inverse elasticity & & & $\begin{array}{c}0.033 \\
{[0.026]}\end{array}$ & & & & \\
\hline Spread & & & & $\begin{array}{c}1.701 \\
{[0.000]}\end{array}$ & & & \\
\hline Volatility & & & & & $\begin{array}{c}0.055 \\
{[0.000]}\end{array}$ & & \\
\hline Issuer size & & & & & & $\begin{array}{c}-0.053 \\
{[0.000]}\end{array}$ & \\
\hline \%onotrade & & & & & & & $\begin{array}{c}0.115 \\
{[0.031]}\end{array}$ \\
\hline Tangibility & $\begin{array}{c}0.020 \\
{[0.573]}\end{array}$ & $\begin{array}{c}-0.006 \\
{[0.859]}\end{array}$ & $\begin{array}{c}0.009 \\
{[0.812]}\end{array}$ & $\begin{array}{c}0.031 \\
{[0.364]}\end{array}$ & $\begin{array}{c}0.045 \\
{[0.223]}\end{array}$ & $\begin{array}{c}0.027 \\
{[0.442]}\end{array}$ & $\begin{array}{c}0.013 \\
{[0.721]}\end{array}$ \\
\hline Distress & $\begin{array}{c}0.188 \\
{[0.002]}\end{array}$ & $\begin{array}{c}0.217 \\
{[0.000]}\end{array}$ & $\begin{array}{c}0.269 \\
{[0.000]}\end{array}$ & $\begin{array}{c}0.235 \\
{[0.000]}\end{array}$ & $\begin{array}{c}0.246 \\
{[0.000]}\end{array}$ & $\begin{array}{c}0.242 \\
{[0.000]}\end{array}$ & $\begin{array}{c}0.273 \\
{[0.000]}\end{array}$ \\
\hline Loss & $\begin{array}{c}0.106 \\
{[0.001]}\end{array}$ & $\begin{array}{c}0.119 \\
{[0.001]}\end{array}$ & $\begin{array}{c}0.134 \\
{[0.000]}\end{array}$ & $\begin{array}{c}0.094 \\
{[0.008]}\end{array}$ & $\begin{array}{c}0.121 \\
{[0.000]}\end{array}$ & $\begin{array}{c}0.098 \\
{[0.006]}\end{array}$ & $\begin{array}{c}0.141 \\
{[0.000]}\end{array}$ \\
\hline Plannedloss & $\begin{array}{c}0.060 \\
{[0.068]}\end{array}$ & $\begin{array}{c}0.085 \\
{[0.010]}\end{array}$ & $\begin{array}{c}0.070 \\
{[0.041]}\end{array}$ & $\begin{array}{c}0.029 \\
{[0.415]}\end{array}$ & $\begin{array}{c}0.028 \\
{[0.406]}\end{array}$ & $\begin{array}{c}0.050 \\
{[0.151]}\end{array}$ & $\begin{array}{c}0.080 \\
{[0.015]}\end{array}$ \\
\hline Highrunup & $\begin{array}{c}0.019 \\
{[0.738]}\end{array}$ & $\begin{array}{c}0.011 \\
{[0.849]}\end{array}$ & $\begin{array}{c}-0.007 \\
{[0.909]}\end{array}$ & $\begin{array}{c}0.024 \\
{[0.650]}\end{array}$ & $\begin{array}{c}-0.024 \\
{[0.661]}\end{array}$ & $\begin{array}{c}0.047 \\
{[0.423]}\end{array}$ & $\begin{array}{c}0.006 \\
{[0.917]}\end{array}$ \\
\hline Underwritten & $\begin{array}{c}-0.043 \\
{[0.103]}\end{array}$ & $\begin{array}{c}-0.038 \\
{[0.176]}\end{array}$ & $\begin{array}{c}-0.041 \\
{[0.146]}\end{array}$ & $\begin{array}{c}0.003 \\
{[0.925]}\end{array}$ & $\begin{array}{c}-0.034 \\
{[0.215]}\end{array}$ & $\begin{array}{c}0.006 \\
{[0.843]}\end{array}$ & $\begin{array}{c}-0.035 \\
{[0.218]}\end{array}$ \\
\hline Industry dummies & Yes & Yes & Yes & Yes & Yes & Yes & Yes \\
\hline Year dummies & Yes & Yes & Yes & Yes & Yes & Yes & Yes \\
\hline$N$ & 430 & 419 & 418 & 430 & 428 & 430 & 430 \\
\hline$R^{2}$ & 0.314 & 0.291 & 0.252 & 0.314 & 0.276 & 0.289 & 0.251 \\
\hline
\end{tabular}


Table 5

OLS regressions with principal component

Elasticity is the first principal component resulting from a principal components analysis involving seven proxies for demand elasticity, namely Relsize1, Relsize3, Inverse elasticity, Spread, Volatility, Issuer size and \%notrade. The continuous variables are defined in Table 1 and the dummy variables, which are from Distress down, are defined in Table 3. The adjustments described in Table 2 are applied. The table reports regression coefficients with heteroscedasticity-robust $p$-values in brackets.

\begin{tabular}{|c|c|c|c|c|c|c|}
\hline & Model 1 & Model 2 & Model 3 & Model 4 & Model 5 & Model 6 \\
\hline Elasticity & $\begin{array}{c}0.061 \\
{[0.000]}\end{array}$ & $\begin{array}{c}0.074 \\
{[0.000]}\end{array}$ & $\begin{array}{c}0.058 \\
{[0.000]}\end{array}$ & $\begin{array}{c}0.074 \\
{[0.000]}\end{array}$ & $\begin{array}{c}0.054 \\
{[0.000]}\end{array}$ & $\begin{array}{c}0.053 \\
{[0.000]}\end{array}$ \\
\hline Tangibility & $\begin{array}{c}0.014 \\
{[0.688]}\end{array}$ & $\begin{array}{c}0.000 \\
{[0.998]}\end{array}$ & & & & \\
\hline$A Q 1: M D D 3$ & & & $\begin{array}{c}0.044 \\
{[0.522]}\end{array}$ & $\begin{array}{c}0.117 \\
{[0.110]}\end{array}$ & & \\
\hline$A Q 2: A M D D$ & & & & & $\begin{array}{c}0.103 \\
{[0.402]}\end{array}$ & \\
\hline$A Q 3: A D A$ & & & & & & $\begin{array}{c}0.057 \\
{[0.644]}\end{array}$ \\
\hline Distress & $\begin{array}{c}0.195 \\
{[0.001]}\end{array}$ & & $\begin{array}{c}0.253 \\
{[0.000]}\end{array}$ & & $\begin{array}{c}0.208 \\
{[0.002]}\end{array}$ & $\begin{array}{c}0.158 \\
{[0.018]}\end{array}$ \\
\hline Loss & $\begin{array}{c}0.072 \\
{[0.035]}\end{array}$ & & $\begin{array}{c}0.088 \\
{[0.019]}\end{array}$ & & $\begin{array}{c}0.076 \\
{[0.060]}\end{array}$ & $\begin{array}{c}0.090 \\
{[0.046]}\end{array}$ \\
\hline Planned loss & $\begin{array}{c}0.040 \\
{[0.234]}\end{array}$ & & $\begin{array}{c}0.019 \\
{[0.524]}\end{array}$ & & $\begin{array}{c}0.017 \\
{[0.575]}\end{array}$ & $\begin{array}{c}0.044 \\
{[0.195]}\end{array}$ \\
\hline Highrunup & $\begin{array}{c}0.017 \\
{[0.767]}\end{array}$ & & $\begin{array}{c}0.033 \\
{[0.510]}\end{array}$ & & $\begin{array}{c}0.020 \\
{[0.691]}\end{array}$ & $\begin{array}{c}0.055 \\
{[0.455]}\end{array}$ \\
\hline Underwritten & $\begin{array}{c}0.007 \\
{[0.805]}\end{array}$ & & $\begin{array}{c}0.022 \\
{[0.469]}\end{array}$ & & $\begin{array}{c}-0.001 \\
{[0.970]}\end{array}$ & $\begin{array}{c}-0.003 \\
{[0.940]}\end{array}$ \\
\hline Industry dummies & Yes & Yes & Yes & Yes & Yes & Yes \\
\hline Year dummies & Yes & Yes & Yes & Yes & Yes & Yes \\
\hline $\begin{array}{l}N \\
R^{2}\end{array}$ & $\begin{array}{c}416 \\
0.348\end{array}$ & $\begin{array}{c}421 \\
0.282\end{array}$ & $\begin{array}{c}342 \\
0.399\end{array}$ & $\begin{array}{c}344 \\
0.313\end{array}$ & $\begin{array}{c}332 \\
0.355\end{array}$ & $\begin{array}{c}264 \\
0.361\end{array}$ \\
\hline
\end{tabular}


Table 6

Quantile regressions

The table reports coefficients that result from minimising a weighted sum of the absolute values of the errors in regressions in which Disc is the dependent variable. For example, the regression quantile for the tenth percentile, q10, results from applying a weight of 0.10 for positive errors and 0.90 for negative errors. $p$-values are based on bootstrapped standard errors using 1,000 replications. The last two columns show differences between coefficients, with $p$-values of a test of the significance of the difference. The continuous variables are defined in Table 1 and the dummy variables, which are from Distress down, are defined in Table 3. The adjustments described in Table 2 are applied.

\begin{tabular}{|c|c|c|c|c|c|c|c|}
\hline & $\mathrm{q} 10$ & $\mathrm{q} 25$ & q50 & q75 & q90 & $\mathrm{q} 75-\mathrm{q} 25$ & q90-q10 \\
\hline Elasticity & $\begin{array}{c}0.011 \\
{[0.009]}\end{array}$ & $\begin{array}{c}0.019 \\
{[0.000]}\end{array}$ & $\begin{array}{c}0.031 \\
{[0.000]}\end{array}$ & $\begin{array}{c}0.050 \\
{[0.000]}\end{array}$ & $\begin{array}{c}0.073 \\
{[0.002]}\end{array}$ & $\begin{array}{c}0.032 \\
{[0.008]}\end{array}$ & $\begin{array}{c}0.062 \\
{[0.013]}\end{array}$ \\
\hline Tangibility & $\begin{array}{c}0.001 \\
{[0.947]}\end{array}$ & $\begin{array}{c}0.008 \\
{[0.575]}\end{array}$ & $\begin{array}{c}0.012 \\
{[0.522]}\end{array}$ & $\begin{array}{c}0.011 \\
{[0.768]}\end{array}$ & $\begin{array}{l}-0.040 \\
{[0.579]}\end{array}$ & $\begin{array}{c}0.003 \\
{[0.941]}\end{array}$ & $\begin{array}{l}-0.041 \\
{[0.567]}\end{array}$ \\
\hline Distress & $\begin{array}{c}0.020 \\
{[0.317]}\end{array}$ & $\begin{array}{c}0.022 \\
{[0.497]}\end{array}$ & $\begin{array}{c}0.094 \\
{[0.508]}\end{array}$ & $\begin{array}{c}0.504 \\
{[0.000]}\end{array}$ & $\begin{array}{c}0.431 \\
{[0.007]}\end{array}$ & $\begin{array}{c}0.482 \\
{[0.000]}\end{array}$ & $\begin{array}{c}0.410 \\
{[0.010]}\end{array}$ \\
\hline Loss & $\begin{array}{c}0.011 \\
{[0.435]}\end{array}$ & $\begin{array}{c}0.007 \\
{[0.640]}\end{array}$ & $\begin{array}{c}0.025 \\
{[0.315]}\end{array}$ & $\begin{array}{c}0.123 \\
{[0.034]}\end{array}$ & $\begin{array}{c}0.289 \\
{[0.055]}\end{array}$ & $\begin{array}{c}0.116 \\
{[0.040]}\end{array}$ & $\begin{array}{c}0.277 \\
{[0.061]}\end{array}$ \\
\hline Plannedloss & $\begin{array}{c}0.010 \\
{[0.497]}\end{array}$ & $\begin{array}{c}0.012 \\
{[0.515]}\end{array}$ & $\begin{array}{c}0.046 \\
{[0.017]}\end{array}$ & $\begin{array}{c}0.029 \\
{[0.320]}\end{array}$ & $\begin{array}{c}0.015 \\
{[0.864]}\end{array}$ & $\begin{array}{c}0.017 \\
{[0.572]}\end{array}$ & $\begin{array}{c}0.005 \\
{[0.949]}\end{array}$ \\
\hline Highrunup & $\begin{array}{c}0.001 \\
{[0.974]}\end{array}$ & $\begin{array}{c}0.002 \\
{[0.931]}\end{array}$ & $\begin{array}{c}0.018 \\
{[0.527]}\end{array}$ & $\begin{array}{c}0.019 \\
{[0.704]}\end{array}$ & $\begin{array}{c}0.061 \\
{[0.807]}\end{array}$ & $\begin{array}{c}0.017 \\
{[0.743]}\end{array}$ & $\begin{array}{c}0.060 \\
{[0.798]}\end{array}$ \\
\hline Underwritten & $\begin{array}{c}-0.006 \\
{[0.535]}\end{array}$ & $\begin{array}{c}0.000 \\
{[0.965]}\end{array}$ & $\begin{array}{c}-0.004 \\
{[0.836]}\end{array}$ & $\begin{array}{c}-0.025 \\
{[0.436]}\end{array}$ & $\begin{array}{c}-0.001 \\
{[0.992]}\end{array}$ & $\begin{array}{c}-0.024 \\
{[0.423]}\end{array}$ & $\begin{array}{c}0.005 \\
{[0.928]}\end{array}$ \\
\hline $\begin{array}{l}\text { Industry dummies } \\
\text { Time dummies }\end{array}$ & $\begin{array}{l}\text { Yes } \\
\text { Yes }\end{array}$ & $\begin{array}{l}\text { Yes } \\
\text { Yes }\end{array}$ & $\begin{array}{l}\text { Yes } \\
\text { Yes }\end{array}$ & $\begin{array}{l}\text { Yes } \\
\text { Yes }\end{array}$ & $\begin{array}{l}\text { Yes } \\
\text { Yes }\end{array}$ & $\begin{array}{l}\text { Yes } \\
\text { Yes }\end{array}$ & $\begin{array}{l}\text { Yes } \\
\text { Yes }\end{array}$ \\
\hline $\begin{array}{l}N \\
\text { Pseudo- } R^{2}\end{array}$ & $\begin{array}{c}416 \\
0.057\end{array}$ & $\begin{array}{c}416 \\
0.072\end{array}$ & $\begin{array}{c}416 \\
0.112\end{array}$ & $\begin{array}{c}416 \\
0.280\end{array}$ & $\begin{array}{c}416 \\
0.407\end{array}$ & 416 & 416 \\
\hline
\end{tabular}




\section{References}

Altinkiliç, O. and R.S. Hansen (2003), 'Discounting and Underpricing in Seasoned Equity Offers', Journal of Finance 69, pp. 285-323.

— and - (2005), 'The Puzzling Wealth Loss around Equity Offerings: Is It merely Price Pressure or Is There More Information?', working paper: ssrn.com/abstract=834044.

Armitage, S. (1998), 'Seasoned Equity Offers and Rights Issues: A Review of the Evidence', European Journal of Finance 4, pp. 29-59.

- (2007), 'Discounts in Placing Pre-renounced Shares in Rights Issues', Journal of Business Finance and Accounting 34, pp. 1345-69.

- (2010), 'Block Buying and Choice of Issue Method in UK Seasoned Equity Offers', Journal of Business Finance and Accounting 37, pp. 422-48.

- (2012), 'The Calculation of Returns during Seasoned Equity Offers', European Journal of Finance, forthcoming.

Armstrong, C., J.E. Core and W.R.Guay (2012), 'When Do Independent Directors Improve Firms' Working Environments?', working paper:

papers.ssrn.com/sol3/papers.cfm?abstract_id=2031801

Bajaj, M., D.J. Denis, S.P. Ferris, and A. Sarin (2001), 'Firm Value and Marketability Discounts', Journal of Corporate Law 27, 89-115.

Barclay, M.J., C.G. Holderness and D.P. Sheehan (2007), 'Private Placements and Managerial Entrenchment', Journal of Corporate Finance 13, pp. 461-84.

Bekaert, G., C. Harvey and C. Lundblad (2007), 'Liquidity and Expected Returns: Lessons from Emerging Markets, Review of Financial Studies 20, pp. 1783-1831.

Brophy, D.J., P.P. Ouimet and C. Sialm (2006), 'Hedge Funds as Investors of Last Resort?', Review of Financial Studies 22, pp. 541-74.

Butler, A., G. Grullon and J.P. Weston (2005), 'Stock Market Liquidity and the Cost of Issuing Equity', Journal of Financial and Quantitative Analysis 40, pp. 331-48.

Chaplinsky, S. and D. Haushalter (2010), 'Financing under Extreme Risk: Contract Terms and Returns to Private Investment in Public Equity', Review of Financial Studies 23, pp. 2789-820.

Chen, H-C., N. Dai and J.D. Schatzberg (2010), 'The Choice of Equity Selling Mechanisms', Journal of Corporate Finance 16, pp. 104-19.

Chen, J., H. Hong and J. Stein (2002), 'Breadth of Ownership and Stock Returns', Journal of Financial Economics 66, pp. 171-205. 
Corwin, S.A. (2003), 'The Determinants of Underpricing for Seasoned Equity Offers', Journal of Finance 58, pp. 2249-79.

Cronqvist, H. and M. Nilsson (2005), 'The Choice between Rights Offerings and Private Equity Placements', Journal of Financial Economics 78, pp. 375-407.

Dai, N. (2007), 'Does Investor Identity Matter? An Empirical Examination of Investments by Venture Capital Funds and Hedge Funds in PIPEs', Journal of Corporate Finance 13, pp. 538-63.

Dai, N., H. Jo and J.D. Schatzberg (2010), 'The Quality and Price of Investment Banks' Service: Evidence from the PIPE Market', Financial Management, Summer, pp. 5895-612.

Dechow, P.M. and I.D. Dichev (2002), 'The Quality of Accruals and Earnings: The Role of Accrual Estimation Errors', Accounting Review 77, pp. 35-59.

Gao, X. and J.R. Ritter (2010), 'The Marketing of Seasoned Equity Offers', Journal of Financial Economics 97, pp. 33-52.

Greene, W.H. (1997), Econometric Analysis, 3rd ed., Macmillan.

Hallock, K.F, R. Madalozzo and C.G. Reck (2010), 'CEO Pay-for-Performance Heterogeneity Using Quantile Regression', Financial Review 45, pp. 1-19.

Hertzel, M., M. Lemmon, J.S. Linck, and L. Rees (2002), 'Long-run Performance Following Private Placements of Equity', Journal of Finance 57, pp. 2595-617.

— and R.L. Smith (1993), 'Market Discounts and Shareholder Gains for Placing Equity Privately', Journal of Finance 48, pp. 459-85.

Huang, R. and D. Zhang (2011), 'Managing Underwriters and the Marketing of Seasoned Equity Offerings', Journal of Financial and Quantitative Analysis 46, pp. 141-70.

Huson, M.R., P.H. Malatesta and R. Parrino (2009), 'The Decline in the Cost of Private Placements', working paper: ssrn.com/abstract $=1356650$.

Intintoli, V. and K.M. Kahle (2009), 'Seasoned Equity Offers: The Effect of Insider Ownership and Float', working paper, ssrn.com/abstract=1352665.

Iqbal, A, S. Espenlaub and N. Strong (2009), 'Earnings Management around UK Open Offers', European Journal of Finance 15, pp. 29-52.

Ivashina V. and Z. Sun (2011), 'Institutional Demand Pressure and the Cost of Corporate Loans', Journal of Financial Economics 99, pp. 500-22.

Kim, K.A. and H-H. Shin (2004), 'The Puzzling Increase in the Underpricing of Seasoned Equity Offerings', The Financial Review 39, pp. 343-65.

Kothari, S.P., A.J. Leone and C.E. Wasley (2005), 'Performance Matched Discretionary Accruals Measures', Journal of Accounting and Economics 39, pp. 163-97. 
Krishnamurthy, S., P. Spindt, V. Subramaniam and T. Woidtke (2005), 'Does Investor Identity Matter in Equity Issues? Evidence from Private Placements', Journal of Financial Intermediation 14, pp. 210-38.

Lee, G. and R.W. Masulis (2009), 'Seasoned Equity Offerings: Quality of Accounting Information and Expected Flotation Costs', Journal of Financial Economics 92, pp. 443-69.

Lesmond, D. (2005), 'Liquidity of Emerging Markets', Journal of Financial Economics 77, pp. 411-452.

Linck, J.S, J.M. Netter and T.Yang (2008), 'The Determinants of Board Structure', Journal of Financial Economics 87, 308-28.

Loderer, C., J. Cooney and L. Van Drunen (1991), 'The Price Elasticity of Demand for Common Stock', Journal of Finance 46, pp. 621-51.

Maynes, E. and A. Pandes (2010), 'The Wealth Effects of Reducing Private Placement Resale Restrictions', working paper: ssrn.com/abstract $=1101038$.

Meidan, D. (2005), 'A Re-examination of Price Pressure around Seasoned Equity Offerings', working paper, ssrn.com/abstract $=534942$.

Moeller, S.B., Schlingemann, F.P and Stulz, R.M. (2005), 'Wealth Destruction on a Massive Scale? A Study of Acquiring-firm Returns in the Recent Merger Wave', Journal of Finance 60, pp, 757-82.

Mola, S. and T. Loughran (2004), 'Discounting and Clustering in Seasoned Equity Offering Prices', Journal of Financial and Quantitative Analysis 39, pp. 1-23.

Myers, S.C. and N.S. Majluf (1984), 'Corporate Financing and Investment Decisions when Firms Have Information that Investors Do Not Have', Journal of Financial Economics 13, pp. 187-221.

Office of Fair Trading (OFT) (2011), Equity Underwriting and Associated Services, OFT report 1303.

Robak, E. (2007), 'Discounts for Illiquid Shares and Warrants: the LiquiStat Database of Transactions on the Restricted Securities Trading Network', working paper: ssrn.com/abstract $=1410709$.

Wruck, K.R. (1989), 'Equity Ownership Concentration and Firm Value: Evidence from Private Equity Financings', Journal of Financial Economics 23, pp. 3-28.

Wruck, K.R. and Y. Wu (2009), 'Relationships, Corporate Governance, and Performance: Evidence from Private Placements of Common Stock', Journal of Corporate Finance 15, pp. $30-47$.

Wu, Y. (2004), 'The Choice of Equity-selling Mechanisms', Journal of Financial Economics 74, pp. 93-119. 